Bài báo khoa học

\title{
Đánh giá đặc điểm khí hậu và điều kiện khí hậu nông nghiệp huyện Kỳ Anh tỉnh Hà Tĩnh
}

\section{Dương Văn Khảm ${ }^{*}$, Đặng Quốc Khánh²}

${ }^{1}$ Viện Khoa học Khí tượng Thủy văn và Biến đổi khí hậu; dvkham.kttv@gmail.com

${ }^{2}$ Tổng Cục Khí tượng Thủy văn; khanhdangkhtc@gmail.com

*Tác giả liên hệ: dvkham.kttv@gmail.com; Tel.: +84-904729009

Ban Biên tập nhận bài: 05/09/2021; Ngày phản biện xong: 13/10/2021; Ngày đăng bài: $25 / 01 / 2022$

Tóm tắt: Kỳ Anh là huyện có điều kiện khí tượng khá phực tạp, luôn phải đối mặt với khí hậu khắc nghiệt, lũ lụt trong mùa mưa, hạn hán kéo dài trong mùa khô, gió Tây Nam khô nóng khốc liệt gây ảnh hưởng rất lớn đến sản xuất nông nghiệp (SXNN). Trên cơ sở các số liệu khí tượng và các số liệu $\mathrm{SXNN}$ ở Kỳ Anh, áp dụng các phương pháp thống kê trong khí hậu $(\mathrm{KH})$, khí hậu nông nghiệp $(\mathrm{KHNN})$, bài báo đã đánh giá một cách có hệ thống các điều kiện $\mathrm{KH}, \mathrm{KHNN}$ ở Kỳ Anh bao gồm điều kiện ánh sáng với tổng số giờ nắng trong năm là 1716 giờ. Nhiệt độ trung bình năm từ $24-25^{\circ} \mathrm{C}$. Biên độ nhiệt độ các tháng đạt $4,4-7,1^{\circ} \mathrm{C}$, biên độ nhiệt độ năm khoảng $5,0-6,0^{\circ} \mathrm{C}$. Tổng nhiệt năm dao động từ $8.000-8.500^{\circ} \mathrm{C}$. Lượng mưa ở Kỳ Anh phổ biến là 2600-3000 mm, nhưng lượng mưa phân bố không đều trong năm. Lượng mưa tích lũy đầu mùa, cuối mùa, xác suất 2-3 tuần khô ướt đã thể hiện quy luật khá rõ ràng về sự phân bố mưa trong năm. Những kết quả này là cơ sở khoa học quan trọng phục vụ quy hoạch $\mathrm{SXNN}$, chuyển đổi cơ cấu cây trồng, giảm thiểu tác hại của thiên tai ở Kỳ Anh.

Từ khóa: Khí hậu (KH); Khí hậu nông nghiệp (KHNN).

\section{Mở đầu}

Nông nghiệp có quan hệ qua lại và phức tạp đối với các điều kiện tự nhiên, trong đó các yếu tố khí hậu là những yếu tố tác động mạnh mẽ nhất đến sản xuất nông nghiệp. Điều kiện khí hậu được xác định cho trồng trọt là: ánh sáng, nhiệt độ, nước và không khí. Đó là những yếu tố không thể thiếu và không thay thế cho nhau được đối với sự sống nói chung, sự sinh trưởng, phát triển và hình thành năng suất, cây trồng nói riêng. Khí hậu không những ảnh hưởng lớn đến sự phân bố địa lý của cây trồng mà còn ảnh hưởng đến nhịp điệu sống, trình tự phát triển trong các giai đoạn sinh trưởng phát triển, chất lượng, năng suất và sản lượng cây trồng [1-3].

Ảnh hưởng của khí hậu và thời tiết đối với nông nghiệp rất rõ nó thể hiện muôn màu, muôn vẻ thuận lợi bất hoà đều có như Dacutraep đã nói “Trong thiên nhiên tất cả đều đẹp đẽ, ngay cả một số nhân tố bất lợi, kẻ thù của sản xuất nông nghiệp như gió lớn, mưa to, hạn hán, gió khô nóng, bão... sở dĩ là đáng sợ với chúng ta vì chúng ta chưa hiểu biết và khống chế nó. Nó không hung dữ chỉ cần chúng ta nghiên cứu biết được cách phòng chống thì lúc đó nó sẽ có lợi cho chúng ta" [4]. Hay Misurin, nhà làm vườn người Nga cũng đã từng nói "Chúng ta không thể chờ đợi sự ban ơn của thiên nhiên mà phải biết đấu tranh với thiên nhiên, đó là nhiệm vụ của chúng ta" [5]. Các nhà nông nghiệp và sinh học phải biết sử dụng hữu hiệu tài nguyên khí hậu để nâng cao hiệu quả sản xuất nông nghiệp và phòng chống thiên 
tai. Đó là con đường rẻ tiền nhất thu được lợi nhuận cao nhất, đồng thời cũng bảo đảm được môi trường sinh thái [6]. Để làm được những việc nêu trên các nhà nông lâm nghiệp và sinh thái học cần phải nắm bắt được bản chất vật lý của các quá trình và hiện tượng xảy ra trong khí quyển nhất là lớp khí quyển sát đất và tác động của chúng đến các đối tượng và quá trình sản xuất nông nghiệp.

Đã từ lâu nhiều nước trên thế giới đã sử dụng các chỉ tiêu KH, KHNN để đánh giá các điều kiện và tài nguyên $\mathrm{KH}, \mathrm{KHNN}$ cho cả nước và phạm vi từng vùng lãnh thổ. Có thể kể đến một số nước sau: Sau chiến tranh thế giới thứ 2 một loạt các nước Đông Âu mà đặc biệt là Liên Xô cũ đã sử dụng các số liệu tại các trạm quan trắc khí tượng, khí tượng nông nghiệp để đánh giá và phân vùng tài nguyên $K H, K H N N$ của nước mình. Thập niên 80 của thế kỷ 20 nhiều nước khác như Trung Quốc, Úc, Ấn Độ, Ý, Israel, Mexico, Việt Nam các nước Châu Phi...cũng đã sử dụng các số liệu quan trắc và áp dụng các phương pháp thống kê để đánh giá các điều kiện khí tượng nông nghiệp và phân vùng KHNN cho cả lãnh thổ và từng khu vực thuộc phạm vi lãnh thổ ở mỗi nước [3, 7-10].

Những nghiên cứu trước đây trong điều kiện biến đổi khí hậu (BĐKH) chưa thực sự mãnh liệt, các điều kiện $\mathrm{KH}, \mathrm{KHNN}$ và hiện tượng thiên tai còn theo quy luật tương đối rõ ràng, dễ năm bắt và đánh giá. Ngày nay, dưới tác động của $B Đ K H$ dẫn đến các điều kiện $K H$, KHNN diễn biến phức tạp, các hiện tượng thời tiết bất thường càng gia tăng về tần suất, độ lớn và độ biến động. Vì vậy, một số kêt quả nghiên cứu và đánh giá trước đây đã không còn phù hợp, các chỉ tiêu KH, KHNN cũng đã có những biến động nhất định, nhất là các tiêu chí thiên tai và các hiện tượng thời tiết cực đoan Do đó, hướng nghiên cứu khí hậu ứng dụng nhằm khai thác sử dụng hợp lý tài nguyên thiên nhiên ngày một trở nên cấp thiết. Nghiên cứu các điều kiện $\mathrm{KH}, \mathrm{KHNN}$ và thể hiện sự phân hoá các điều kiện đó trên cơ sở khoa học phục vụ quy hoạch, khai thác tài nguyên thiên nhiên, sử dụng lãnh thổ một cách hợp lý đang ngày càng có tính thời sự cao nhất là trong bối cảnh $\mathrm{BĐKH} \mathrm{hiện} \mathrm{nay.} \mathrm{Đây} \mathrm{là} \mathrm{một} \mathrm{bước} \mathrm{cụ} \mathrm{thể} \mathrm{hoá}$ các kết quả nghiên cứu vào thực tiễn.

\section{Phương pháp nghiên cứu}

\subsection{Giới thiệu khu vục nghiên cúu}

Kỳ Anh là huyện có nhiều lợi thế phát triển trồng trọt, vùng có tiềm năng đất đai rộng lớn với nhiều loại đất cùng với nguồn tài nguyên KHNN đa dạng và phong phú (Hình 1). Tuy nhiên, vùng này còn gặp không ít khó khăn về nhiều mặt, cụ thể như: địa hình đồi núi phức tạp dẫn đến điều kiện khí tượng thủy văn diễn biến phức tạp thay đổi lớn trên phạm vi hẹp, đất dốc chiếm diện tích lớn. Đặc biệt, vùng này luôn phải đối mặt với điều kiện khí hậu khắc nghiệt, lũ lụt trong mùa mưa, hạn hán kéo dài nhiều tháng trong mùa khô, gió Tây Nam khô nóng gây ảnh hưởng rất lớn đến sản xuất nông lâm nghiệp $[5,9]$. Do đó, tốc độ phát triển ngành trồng trọt còn chậm, chưa tương xứng với tiềm năng của từng địa phương. Việc đánh giá một cách có hệ thống các điều kiện khí khí hậu, KHNN phục vụ quy hoạch và phát triển ngành trồng trọt, chuyển đổi cơ cấu cây trồng phù hợp, giảm thiểu tác động của thiên tai ở trong $\mathrm{SXNN}$ ở Kỳ Anh là rất cần thiết.

\subsection{Số liệu thu thập nghiên cưu}

Nghiên cứu sử dụng số liệu khí tượng ngày của 5 trạm khí tượng cơ bản đại diện cho khu vực huyện Kỳ Anh bao gồm các trạm: Kỳ Anh, Hà Tĩnh, Hương Khê, Tuyên Hoá và Ba Đồn thời kỳ 1961-2020. Số liệu Niên giám thống kê của tỉnh Hà Tĩnh và các báo cáo có liên quan đến $\mathrm{SXNN}$ như: cơ cấu thời vụ, diện tích gieo trồng, năng suất, sản lượng, tình hình thiên tai [11-12].

\subsection{Phưong pháp đánh giá điều kiện khi hậu, khi hậu nông nghiệp}

Yêu cầu của cây trồng về điều kiện khí hậu ở một giai đoạn sinh trưởng nào đó có thể được xác định một cách định lượng thông qua các chỉ số KHNN ở từng khu vực cụ thể. 


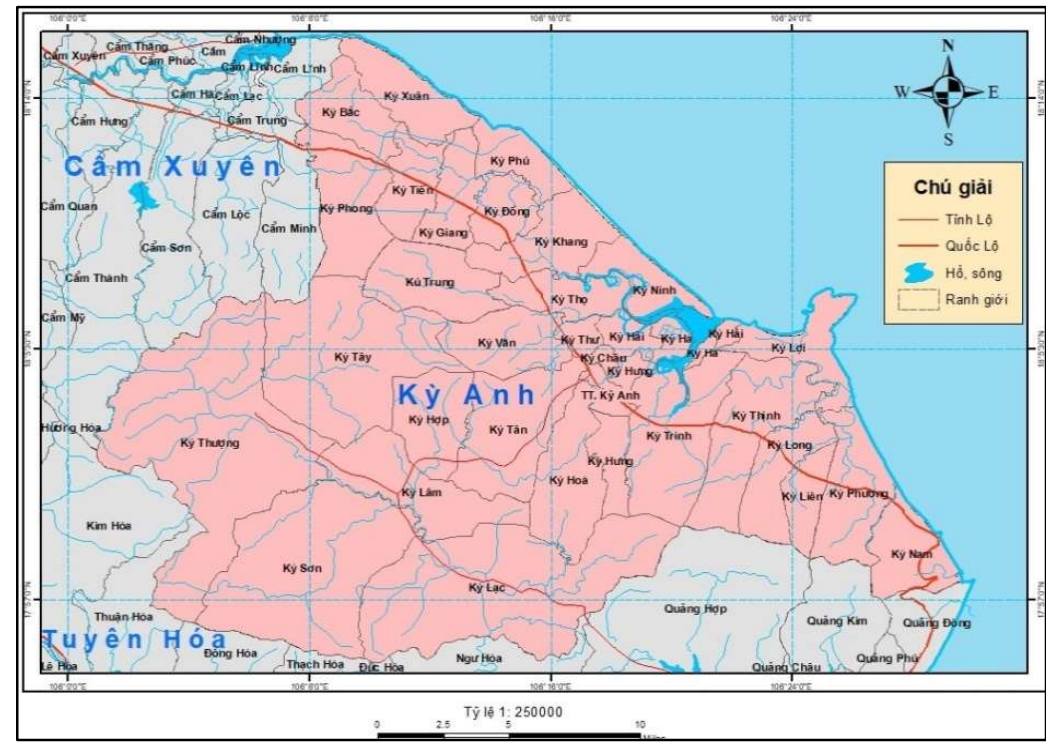

Hình 1. Khu vực nghiên cứu.

Để xác định các chỉ số KHNN có thể sử dụng nhiều phương pháp khác nhau, dưới đây là một số phương pháp thường được áp dụng rộng rãi trong nghiên cứu KHNN [13-16]:

+ Trung bình số học $\bar{x}$ :

$$
\bar{x}=\frac{1}{n} \sum_{i=1}^{n} x_{i}
$$

Trong đó $\mathrm{x}_{\mathrm{i}}$ là đại lượng khí hậu $\mathrm{X}$ có các quan trắc ngày/tháng là $\left\{\mathrm{x}_{\mathrm{i}}, \mathrm{i}=1 . . \mathrm{n}\right\}$.

+ Biên độ nhiệt độ ngày là hiệu giữa giá trị lớn nhất và giá trị nhỏ nhất trong ngày. Ký hiệu biên độ là $\mathrm{QA}$, ta có: $\mathrm{QA}=\mathrm{x}_{\max }-\mathrm{x}_{\min }$.

+ Tổng tích nhiệt độ hàng năm:

$$
\text { Tổng tích nhiệt }=\sum_{i=1}^{n} x_{i}
$$

Trong đó $\mathrm{x}_{\mathrm{i}}$ là nhiệt độ không khí ngày $\left\{\mathrm{x}_{\mathrm{i}}, \mathrm{i}=1 . . \mathrm{n}\right\}, \mathrm{n}$ là độ dài trong vụ Đông Xuân (từ tháng $12-6)$, vụ Mùa (từ $7-10)$ và tổng năm (365 ngày).

+ Ngày bắt đầu và kết thúc nhiệt độ qua $20^{\circ} \mathrm{C}$ và $25^{\circ} \mathrm{C}\left(n_{k}\right)$ được xác định theo công thức.

$$
n_{k}=n g \text { ày } 15 \text { tháng } i+\frac{\bar{T}_{l}-k}{\bar{T}_{i}-\bar{T}_{i+1}} D_{i}
$$

Trong đó $\mathrm{i}, \mathrm{i}+1$ là hai tháng kết tiếp, trong đó nhiệt độ trung bình của tháng $\mathrm{i}\left(\bar{T}_{i}\right)$ cao hơn (thấp hơn) và tháng $\mathrm{i}+1\left(\bar{T}_{i+1}\right)$ thấp hơn (cao hơn) mức $\mathrm{k}$, và $\mathrm{D}_{\mathrm{i}}$ là số ngày trong tháng i. Trong đó $\mathrm{k}=20^{\circ} \mathrm{C}$ và $25^{\circ} \mathrm{C}$.

+ Tính tuần khô tuần ướt:

Xác suất 2 và 3 tuần khô liên tục;

Xác suất tuần khô $\mathrm{P}(\mathrm{k})=\mathrm{F}(\mathrm{k}) / \mathrm{n}$

Xác suất tuần ướt khi có tuần ướt trước đó: $\mathrm{P}(\mathrm{kk})=\mathrm{F}(\mathrm{k}) / \mathrm{F}(\mathrm{kk})$

Xác suất tuần ướt: $\mathrm{P}(\mathrm{w})=\mathrm{F}(\mathrm{w}) / \mathrm{n}$

Xác suất tuần ướt khi có tuần ướt trước đó: $\mathrm{P}(\mathrm{ww})=\mathrm{F}(\mathrm{w}) / \mathrm{F}(\mathrm{w})$

Xác suất của hai tuần khô liên tục: $\mathrm{P}(\mathrm{k} 1 \mathrm{l})=\mathrm{P}(\mathrm{k}) \times \mathrm{P}(\mathrm{kk})$

Xác suất của hai tuần khô liên tục: $\mathrm{P}($ wll $)=\mathrm{P}(\mathrm{w}) \times \mathrm{P}(\mathrm{ww})$

Trong đó $\mathrm{F}(\mathrm{k})$ là số tuần ướt; $\mathrm{F}(\mathrm{kk})$ là số tuần ướt khi có tuần ướt trước đó; $\mathrm{F}(\mathrm{w})$ là số tuần ướt; $\mathrm{F}(\mathrm{ww})$ là số tuần ướt khi có tuần ướt trước đó.

+ Xác định suất bảo đảm cho tính toán lượng mưa tích lũy 
Trong khí hậu để tính xác suất mà đại lượng khí hậu X nhận giá trị trong một khoảng $\left(\mathrm{a}_{\mathrm{j}}\right.$, $\mathrm{b}_{\mathrm{j}}$ ) nào đó khi đã biết hàm phân bố $\mathrm{F}(\mathrm{x})$ :

$$
\begin{array}{r}
\mathrm{P}\left(\mathrm{a}_{\mathrm{j}} \leq \mathrm{X}<\mathrm{b}_{\mathrm{j}}\right)=\mathrm{F}\left(\mathrm{b}_{\mathrm{j}}\right)-\mathrm{F}\left(\mathrm{a}_{\mathrm{j}}\right) \\
\mathrm{P}(\mathrm{X} \geq \mathrm{x})=1-\mathrm{F}(\mathrm{x})=\Phi(\mathrm{x})
\end{array}
$$

Trong khí hậu $\Phi(\mathrm{x})$ được gọi là suất bảo đảm, tức là xác suất để $\mathrm{X}$ nhận giá trị vượt quá $\mathrm{x}$.

Trên cơ sở các phương pháp nêu trên, cho đến nay đã có nhiều chỉ số KHNN khác nhau được lựa chọn trong đánh giá và khai thác tài nguyên KHNN. Những chỉ số này được phân thành 5 nhóm chính sau: i) Nhóm chỉ số về tài nguyên bức xạ và ánh sáng; ii) Nhóm chỉ số về điều kiện sống qua đông của cây trồng; iii) Nhóm chỉ số về tài nguyên nhiệt; iv) Nhóm chỉ số về tài nguyên ẩm; v) Nhóm chỉ số về hiện tương thời tiết bất lợi.

Từ những chỉ số KHNN này sẽ là cơ sở trong việc đánh giá một cách có hệ thống các điều kiện KHNN ảnh hưởng đến quá trình sinh trưởng, phát triển và hình thành năng suất cây trồng đối với từng mùa, từng vùng cụ thể.

\section{Kết quả và thảo luận}

\section{1. Đặc điểm chung khỉ hậu huyện Kỳ Anh}

Đặc điểm khí hậu nổi bật ở đây là mùa mưa lệch về mùa đông (đến giữa mùa đông). Trong thời kỳ gió mùa mùa hạ ở đây có nhiều đợt gió tây khô nóng rất khắc nghiệt. Mức độ khô nóng ở đây gắn chặt với cơ chế của gió mùa tây nam. Thời kỳ có gió Lào là thời kỳ khô và nóng bức nhất trong năm. Tháng 7 là tháng thịnh hành nhất của gió mùa tây nam trở thành tháng nóng nhất và khô nhất trong năm ở vùng này. Những đợt gió Lào mạnh, khô nóng kéo dài (có khi tới 20-30 ngày) thường làm cho sông suối, hồ khô cạn, đồng ruộng nứt nẻ; cây cối, hoa màu,...khô cháy; sức khoẻ con người bị ảnh hưởng rất đáng kể. Nhiệt độ cao nhất có thể đạt trên $42^{\circ} \mathrm{C}$. Ở vùng này lượng mưa từ đầu mùa đến tháng 6 , tháng 7 chẳng những không tăng lên theo quy luật chung, mà thậm chí lại bị giảm xuống, tạo nên hiện tượng hạn cục bộ rất đặc trưng. Mưa ở đây bắt đầu tăng từ tháng 8 và đạt cực đại vào tháng 10 với lượng mưa gấp 3-4 lần các tháng khác. Thời kỳ đầu mùa đông ở đây cũng là thời kỳ độ ẩm đạt giá trị cao nhất trong năm. Ngược với tình hình khô hạn trong tháng 6 , tháng 7 , lượng mưa tháng 9 và tháng 10 lại vượt trội, chiếm tới $40-50 \%$ lượng mưa cả năm. Tình hình mưa lớn đó kéo theo nạn lũ lụt nghiêm trọng ở Kỳ Anh. Nhiệt độ trung bình các tháng cao điểm trong mùa đông chưa vượt qua giới hạn $20^{\circ} \mathrm{C}$, do không khí lạnh và front cực đới cũng ảnh hưởng đáng kể đến vùng này. Ảnh hưởng của bão ở Kỳ Anh rất lớn. Bão ở đây hoạt động phổ biến vào tháng 9. Bão thường đem lại mưa to, gió lớn. Cường độ mưa bão có thể đạt tới 300-400 $\mathrm{mm} /$ ngày và tốc độ gió bão có thể vượt quá $40 \mathrm{~m} / \mathrm{s}$ [9, 17-18].

Có thể nói vùng Kỳ Anh là vùng có điều kiện khí hậu tương đối khắc nghiệt: mùa đông vẫn còn khá lạnh, mùa hạ nhiều nắng, nóng bức và khô hạn; mưa lớn tập trung vào mùa mưa bão, gây ra lũ lụt ảnh hưởng rất nghiêm trọng đến sản xuất và đời sống của nhân dân. Trong những trường hợp gió mùa đông bắc rất mạnh tràn về nhiệt độ ở đây bị hạ thấp đáng kể và cũng có thể xảy ra sương muối. Hình 2 là biến trình năm một số yếu tố khí hậu ở Kỳ Anh đã chứng minh một số nhận định chung về đặc điểm khí hậu ở Kỳ Anh.

\section{2. Điều kiện KHNN ở huyện Kỳ Anh}

\subsection{1. Điều kiện ánh sáng đối với SXNN}

Đối với cây trồng, điều kiện ánh sáng có ý nghĩa rất quan trọng. Cây trồng thông qua quang hợp để chuyển đổi thành năng lượng hoá học nhằm tạo ra năng suất. Điều kiện ánh sáng thường được đánh giá thông qua số giờ nắng [19]. Từ kết quả tính toán ở Bảng 1 nhận 
thấy: số giờ nắng ở huyện Kỳ Anh khá cao-cao nhất so với các khu vực khác ở Hà Tĩnh. Tổng số giờ nắng trong năm ở huyện Kỳ Anh là 1716 giờ.

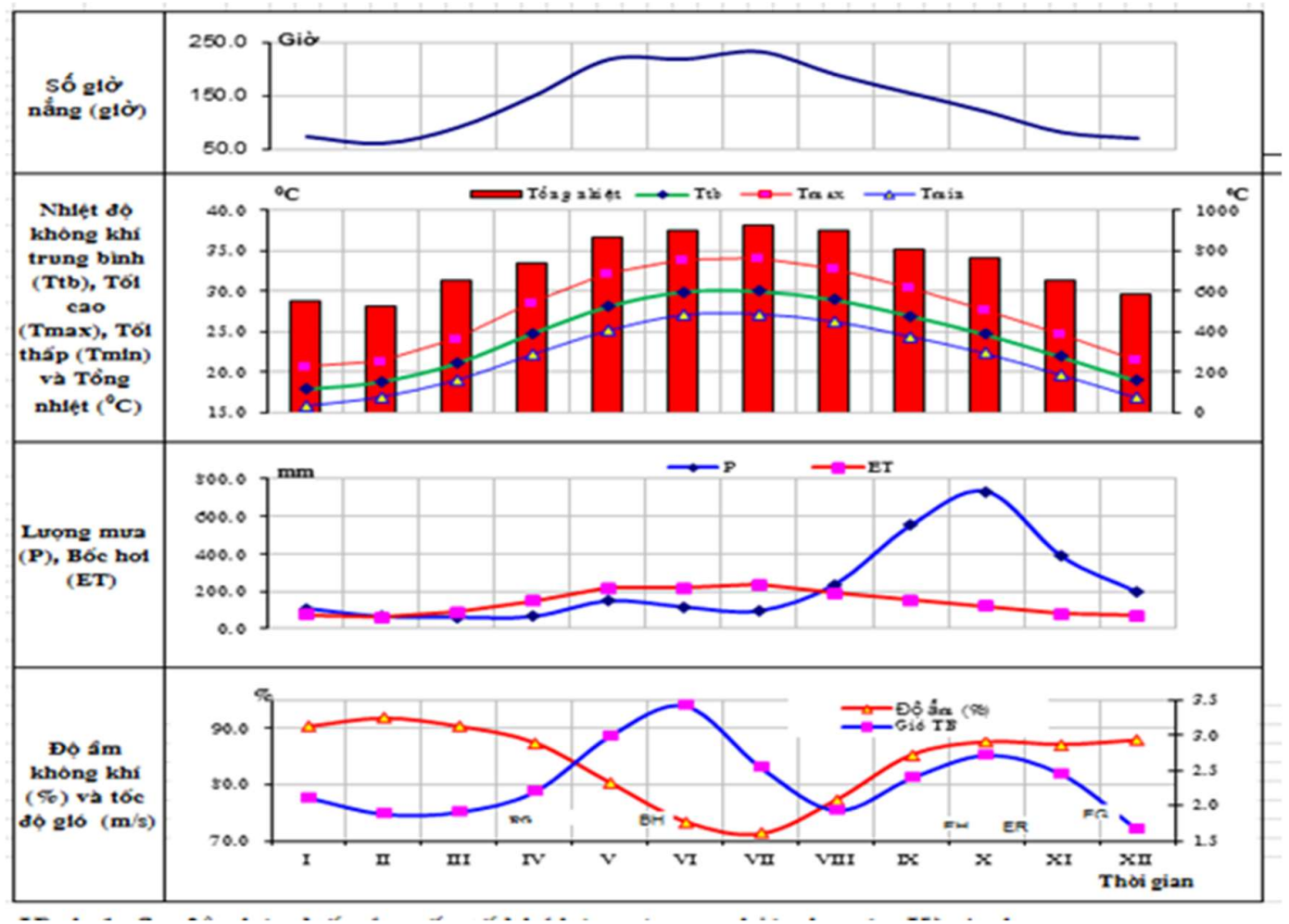

Hình 2. Biến trình của một số yếu tố khí hậu ở huyện Kỳ Anh.

Tháng có số giờ nắng cao nhất là tháng V, VI, VII dao động từ 220 đến 242 giờ/tháng, tháng có ít nắng nhất là tháng XII, I, II dao động từ 60-79 giờ/tháng. Như vậy số giờ nắng phân bố trong năm rất không đồng đều, vụ đông xuân thường thiếu ánh sáng, trong khi đó vụ hè thu lại quá dư thừa. Vì vậy, việc bố trí mật độ và loại cây trồng thích hợp trong từng thời kỳ rất có ý nghĩa trong việc tăng năng suất cây trồng... Đây cũng là căn cứ tốt để đánh giá khả năng khai thác nguồn năng lượng này trong lĩnh vực sản xuất muối đối với huyện ven biển Kỳ Anh nói riêng và tỉnh Hà Tĩnh nói chung.

Bảng 1. Số giờ nắng trung bình tháng ở Kỳ Anh và các vùng lân cận (giờ).

\begin{tabular}{|c|c|c|c|c|c|c|c|c|c|c|c|c|c|}
\hline \multirow{2}{*}{ Trạm } & \multicolumn{12}{|c|}{ Tháng } & \multirow[t]{2}{*}{ Năm } \\
\hline & I & II & III & IV & $\mathbf{V}$ & VI & VII & VIII & IX & $\mathbf{X}$ & XI & XII & \\
\hline $\begin{array}{c}\text { Kim } \\
\text { Cương }\end{array}$ & 65,4 & 50,8 & 73,5 & 132,9 & 202,1 & 172,3 & 199,8 & 149,1 & 140,1 & 116,3 & 82,9 & 75,1 & 1460 \\
\hline Hà Tĩnh & 76,9 & 51,1 & 75,9 & 136,4 & 219,3 & 207,7 & 230,7 & 190,5 & 158,8 & 135,8 & 95,8 & 81,6 & 1661 \\
\hline $\begin{array}{c}\text { Hương } \\
\text { Khê }\end{array}$ & 68,6 & 50,1 & 81,0 & 132,3 & 184,1 & 184,7 & 212,4 & 167,3 & 125,3 & 103,7 & 72,4 & 62,4 & 1444 \\
\hline Kỳ Anh & 78,7 & 60,1 & 94,5 & 152,5 & 226,5 & 221,7 & 241,5 & 195,7 & 162,7 & 125,7 & 80,6 & 75,3 & 1716 \\
\hline $\begin{array}{c}\text { Tuyên } \\
\text { Hoá }\end{array}$ & 75,4 & 62,8 & 110,3 & 147,8 & 201,9 & 200,3 & 221,3 & 181,6 & 126,3 & 108,3 & 73,9 & 63,1 & 1573 \\
\hline Ba Đồn & 99,5 & 75,1 & 111,7 & 164,9 & 229,2 & 218,6 & 241,2 & 201,7 & 166,5 & 137,7 & 95,9 & 88,2 & 1830 \\
\hline
\end{tabular}




\subsection{2. Điều kiện nhiệt độ đối với $\mathrm{SXNN}$}

Nhiệt độ là một trong những yếu tố môi trường có ảnh hưởng phức tạp đến đời sống cây trồng. Khi sống trong điều kiện môi trường có nhiệt độ thích hợp cây trồng sẽ sinh trưởng và phát triển tốt và nếu ngược lại thì mọi quá trình sống sẽ bị hạn chế. Đối với việc bố trí cơ cấu cây trồng, xác định khả năng có thể trồng được mấy vụ trong một năm thì các chỉ tiêu biến trình năm của nhiệt độ, tổng nhiệt độ từng vụ và cả năm là rất quan trọng. Đồng thời cũng cần biết biên độ nhiệt độ ngày đềm để thấy được khả năng tích luỹ chất khô và mức độ hô hấp của cây trồng. Ngoài ra chỉ tiêu ngày bắt đầu và kết thúc của các ngưỡng nhiệt độ cũng rất cần thiết để bố trí cơ cấu cây trồng hợp lý ở từng vùng cụ thể [1, 20-22].

a) Nhiệt độ không khi trung bình

Từ kết quả tính toán Bảng 2 cho thấy nhiệt độ trung bình năm ở khu vực huyện Kỳ Anh khá cao khoảng $24.2^{\circ} \mathrm{C}$, tháng lạnh nhất là tháng $\mathrm{I}\left(17,9^{\circ} \mathrm{C}\right)$, tháng nóng nhất là tháng $\mathrm{VI}$ và VII $\left(29,5-30.0^{\circ} \mathrm{C}\right)$.

Bảng 2. Nhiệt độ không khí trung bình tháng và năm ở Kỳ Anh và khu vực lân cận.

\begin{tabular}{|c|c|c|c|c|c|c|c|c|c|c|c|c|c|}
\hline \multirow[b]{2}{*}{ Trạm } & \multicolumn{12}{|c|}{ Tháng } & \multirow[b]{2}{*}{ Năm } \\
\hline & I & II & III & IV & $\mathbf{V}$ & VI & VII & VIII & IX & $\mathbf{X}$ & XI & XII & \\
\hline Hà Tĩnh & 17,6 & 18,2 & 20,8 & 24,3 & 27,7 & 29,4 & 29,6 & 28,7 & 26,8 & 24,3 & 21,4 & 18,7 & 24,0 \\
\hline Hương Khê & 17,6 & 18,4 & 21,2 & 24,9 & 27,6 & 28,8 & 29,2 & 28,0 & 26,0 & 23,8 & 20,9 & 18,3 & 23,7 \\
\hline Kỳ Anh & 17,9 & 18,5 & 20,9 & 24,6 & 28,0 & 29,7 & 29,9 & 28,9 & 26,9 & 24,5 & 21,6 & 18,8 & 24,2 \\
\hline Tuyên Hoá & 18,0 & 19,0 & 21,6 & 25,0 & 27,7 & 29,1 & 29,3 & 28,2 & 26,2 & 23,8 & 21,0 & 18,5 & 24,0 \\
\hline Ba Đồn & 18,7 & 19,2 & 21,7 & 24,7 & 27,8 & 29,6 & 29,7 & 28,9 & 27,0 & 24,8 & 22,0 & 19,4 & 24,5 \\
\hline
\end{tabular}

b) Biên độngày đêm của nhiệt độ không khí

Biên độ ngày đêm của nhiệt độ là chênh lệch giữa nhiệt độ cao nhất và thấp nhất trong ngày được xem như là một chỉ tiêu để phân loại khí hậu. Đối với SXNN biên độ nhiệt độ ngày đêm của không khí có tác dụng rất lớn đối với quá trình sinh trưởng, phát triển của cây trồng, đặc biệt trong quá trình quang hợp ban ngày và hô hấp ban đêm để tích luỹ vật chất. Do đó, đối với từng vùng thì thời gian có biên độ ngày lớn chính là thời gian thích hợp và thuận lợi đối với quá trình ra hoa, tạo quả và làm hạt (củ) của nhiều loại cây trồng $[3-4,14]$.

Bảng 3 cho thấy ở Kỳ Anh gió tây khô nóng nhiều thì biên độ ngày đêm thấp vào mùa đông và cao hơn vào mùa hè. Cụ thể như sau: ở khu vực này có biên độ nhiệt độ không cao vào các tháng mùa hè khoảng từ $6.0-7.0^{\circ} \mathrm{C}$, các tháng mùa đông khoảng từ $4.4-5.0^{\circ} \mathrm{C}$.

Bảng 3. Biên độ của nhiệt độ không khí ở huyện Kỳ Anh và các khu vực lân cận.

\begin{tabular}{|c|c|c|c|c|c|c|c|c|c|c|c|c|c|}
\hline \multirow{2}{*}{ Trạm } & \multicolumn{12}{|c|}{ Tháng } & \multirow[b]{2}{*}{ Năm } \\
\hline & I & II & III & IV & $\mathrm{V}$ & VI & VII & VIII & IX & $X$ & XI & XII & \\
\hline Hà Tĩnh & 4,9 & 4,4 & 5,1 & 6,3 & 7,5 & 7,6 & 8,1 & 7,3 & 6,4 & 5,6 & 5,3 & 5,1 & 6,1 \\
\hline Hương Khê & 6,2 & 5,9 & 6,9 & 8,7 & 9,5 & 9,2 & 9,7 & 8,7 & 7,7 & 6,6 & 6,3 & 6,1 & 7,6 \\
\hline Kỳ Anh & 4,8 & 4,4 & 5,1 & 6,4 & 7,1 & 6,7 & 6,9 & 6,7 & 6,0 & 5,5 & 5,2 & 4,9 & 5,8 \\
\hline Tuyên Hoá & 6,1 & 6,0 & 7,6 & 9,1 & 9,6 & 8,5 & 8,7 & 8,5 & 7,7 & 6,5 & 6,1 & 5,8 & 7,5 \\
\hline
\end{tabular}

c) Nhiệt độ tối thấp tuyệt đối trung bình năm

Hàng năm về mùa đông rất nhiều nơi thuộc vùng núi cao ở huyện Kỳ Anh nhiệt độ thường xuống thấp tới mức có hại cho cây trồng. Những loại cây lâu năm không những cần điều kiện nhiệt độ thích hợp trong mùa sinh trưởng mà còn cần điều kiện sống qua mùa đông một cách an toàn. Do đó, khi nghiên cứu bố trí cây trồng, nhất là những cây lâu năm thì không những cần phải dựa vào những điều kiện $\mathrm{KHNN}$ mà còn phải đặc biệt chú ý đến điều kiện sống qua mùa đông của cây trồng $[3,22-23]$. 
Từ bảng 4 thấy rằng nhiệt độ tối thấp tuyệt đối năm ở Kỳ Anh là $6.9^{\circ} \mathrm{C}$, khu vực xung quanh huyện Kỳ Anh từ $0,7^{\circ} \mathrm{C}$ (Kim Cương), $2,6^{\circ} \mathrm{C}$ (Hương Khê) đến $6,8^{\circ} \mathrm{C}$ ở Hà Tĩnh và $5,0^{\circ} \mathrm{C}$ ở Tuyên Hóa. Như vậy huyện Kỳ Anh là nơi có nhiệt độ tối thấp tuyệt đối khá cao so với khu vực xung quanh, đây là điều kiện thuận lợi để phát triển các loại cây trồng có nguồn gốc nhiệt đới.

Bảng 4. Nhiệt độ tối thấp tuyệt đối ở huyện Kỳ Anh và các khu vực lân cận.

\begin{tabular}{|c|c|c|c|c|c|c|c|c|c|c|c|c|c|}
\hline \multirow{2}{*}{ Trạm } & \multicolumn{12}{|c|}{ Tháng } & \multirow{2}{*}{$\begin{array}{l}\text { Tmin } \\
\text { Năm }\end{array}$} \\
\hline & I & II & III & IV & $\mathbf{V}$ & VI & VII & VIII & IX & $\mathbf{X}$ & XI & XII & \\
\hline Kim Cương & 0,7 & 5,1 & 4,3 & 10,6 & 14,4 & 17,0 & 20,8 & 20,4 & 17,2 & 12,1 & 7,2 & 2,3 & 0,7 \\
\hline Hà Tĩnh & 7,3 & 8,0 & 8,2 & 13,3 & 17,3 & 19,5 & 22,0 & 22,3 & 17,0 & 15,1 & 11,3 & 6,8 & 6,8 \\
\hline Hương Khê & 2,6 & 6,7 & 7,6 & 11,8 & 16,0 & 19,0 & 20,4 & 20,4 & 17,2 & 13,5 & 6,6 & 2,9 & 2,6 \\
\hline Kỳ Anh & 7,5 & 8,1 & 7,4 & 13,2 & 14,8 & 19,9 & 22,2 & 22,1 & 17,3 & 15,2 & 11,2 & 6,9 & 6,9 \\
\hline Tuyên Hoá & 5,4 & 7,8 & 7,2 & 12,4 & 16,3 & 19,3 & 21,4 & 21,6 & 17,1 & 13,9 & 10,3 & 5,0 & 5,0 \\
\hline Ba Đồn & 7,9 & 9,1 & 7,8 & 13,4 & 18,1 & 20,4 & 21,7 & 21,3 & 18,0 & 16,0 & 12,3 & 7,6 & 7,6 \\
\hline
\end{tabular}

d) Ngày bắt đầu, kết thúc nhiệt độ qua $20^{\circ} \mathrm{C}, 25^{\circ} \mathrm{C}$

Ngày bắt đầu và kết thúc mùa đông lạnh (ngày bắt đầu và kết thúc nhiệt độ $20^{\circ} \mathrm{C}$ )

Thời kỳ có nhiệt độ xuống dưới $20^{\circ} \mathrm{C}$ là mùa đông và là thời kỳ sinh trưởng của các cây trồng xứ lạnh như khoai tây, rau, đậu đỗ có nguồn gốc ôn đới $[1,12,24]$. Để xác định thời vụ tối ưu cho các cây trồng này bài viết đã tính toán được ngày bắt đầu và kết thúc nhiệt độ qua $20^{\circ} \mathrm{C}$ ứng với các suất bảo đảm khác nhau. Kết quả tính toán được trình bày trong Bảng 5 .

Bảng 5. Suất bảo đảm ngày bắt đầu, ngày kết thúc có nhiệt độ qua $20^{\circ} \mathrm{C}$ trạm $\mathrm{Kỳ} \mathrm{Anh}$

\begin{tabular}{lccccccccccc}
\hline $\begin{array}{l}\text { Suất bảo đảm } \\
\text { (\%) }\end{array}$ & $\mathbf{5}$ & $\mathbf{1 0}$ & $\mathbf{2 0}$ & $\mathbf{3 0}$ & $\mathbf{4 0}$ & $\mathbf{5 0}$ & $\mathbf{6 0}$ & $\mathbf{7 0}$ & $\mathbf{8 0}$ & $\mathbf{9 0}$ & $\mathbf{9 5}$ \\
\hline Ngày bắt đầu & $9 / \mathrm{XI}$ & $16 / \mathrm{XI}$ & $20 / \mathrm{XI}$ & $24 / \mathrm{XI}$ & $27 / \mathrm{XI}$ & $30 / \mathrm{XI}$ & $03 / \mathrm{XII}$ & $12 / \mathrm{XII}$ & $13 / \mathrm{XII}$ & $23 / \mathrm{XII}$ & $30 / \mathrm{XII}$ \\
Ngày kết thúc & $01 / \mathrm{II}$ & $12 / \mathrm{II}$ & $28 / \mathrm{II}$ & $10 / \mathrm{III}$ & $12 / \mathrm{III}$ & $13 / \mathrm{III}$ & $14 / \mathrm{III}$ & $16 / \mathrm{III}$ & $20 / \mathrm{III}$ & $28 / \mathrm{III}$ & $03 / \mathrm{IV}$ \\
\hline
\end{tabular}

Ngày bắt đầu và kết thúc mùa nóng (ngày bắt đầu và kết thúc nhiệt độ $25^{\circ} \mathrm{C}$ )

Thời kỳ có nhiệt độ không khí trung bình trên $25^{\circ} \mathrm{C}$ (mùa nóng): Có ý nghĩa trong việc xác định và bố trí để cây trồng trùng với thời kỳ ra hoa-làm quả tốt nhất cho các cây lương thực, thực phẩm, (thời kỳ trỗ cho lúa, phun râu trỗ cờ của ngô, ra hoa-làm quả của đậu tương, ra hoa-làm quả của lạc...) $[1,14,22]$. Ngày bắt đầu và kết thúc nhiệt độ qua $25^{\circ} \mathrm{C}$ ứng với các suất bảo đảm khác nhau được trình bày trong Bảng 6 .

Bảng 6. Suất bảo đảm ngày bắt đầu, ngày kết thúc có nhiệt độ qua $25^{\circ} \mathrm{C}$ trạm Kỳ Anh.

\begin{tabular}{ccccrrrrrrrr}
\hline $\begin{array}{c}\text { Suất bảo đảm } \\
(\mathbf{\%})\end{array}$ & $\mathbf{5}$ & $\mathbf{1 0}$ & $\mathbf{2 0}$ & $\mathbf{3 0}$ & $\mathbf{4 0}$ & $\mathbf{5 0}$ & $\mathbf{6 0}$ & $\mathbf{7 0}$ & $\mathbf{8 0}$ & $\mathbf{9 0}$ & $\mathbf{9 5}$ \\
\hline Ngày bắt đầu & $27 / \mathrm{III}$ & $31 / \mathrm{III}$ & $7 / \mathrm{IV}$ & $12 / \mathrm{IV}$ & $16 / \mathrm{IV}$ & $19 / \mathrm{IV}$ & $21 / \mathrm{IV}$ & $23 / \mathrm{IV}$ & $24 / \mathrm{IV}$ & $26 / \mathrm{IV}$ & $28 / \mathrm{IV}$ \\
Ngày kết thúc & $28 / \mathrm{IX}$ & $01 / \mathrm{X}$ & $4 / \mathrm{X}$ & $5 / \mathrm{X}$ & $6 / \mathrm{X}$ & $8 / \mathrm{X}$ & $11 / \mathrm{X}$ & $13 / \mathrm{X}$ & $16 / \mathrm{X}$ & $20 / \mathrm{X}$ & $24 / \mathrm{X}$ \\
\hline
\end{tabular}

e) Tích nhiệt

Tích nhiệt là đơn vị biểu hiện thời gian cần thiết thực vật hoàn thành một giai đoạn hay cả một vòng đời sinh trưởng và phát triển. Thông qua tích nhiệt năm ở một vùng nào đó có thể biết được khả năng gieo trồng được mấy vụ cho cây hàng năm $[4,14,25]$. Kết quả tính toán tổng nhiệt năm và tổng nhiệt theo vụ được trình bày trong Bảng 7 . Tích nhiệt ở huyện 
Kỳ Anh và các vùng lân cận cho cả năm và từng vụ là khá phong phú, cơ bản đáp ứng về tổng nhiệt cho hầu hết các cây trồng vùng nhiệt đới.

Bảng 7. Tích nhiệt theo vụ và năm ở Kỳ Anh và các vùng lân cận $\left({ }^{\circ} \mathrm{C}\right)$.

\begin{tabular}{lccc}
\hline Địa điểm & Vụ Đông xuân (XII-V) & Vụ Hè thu (VI-X) & Cả năm \\
\hline Hà Tĩnh & 4048,6 & 4246,6 & 8295,2 \\
Hương Khê & 4074,5 & 4155,0 & 8229,5 \\
Kỳ Anh & 4095,0 & 4280,3 & 8375,3 \\
Tuyên Hoá & 4129,8 & 4179,3 & 8309,1 \\
Ba Đồn & 4170,2 & 4283,4 & 8453,6 \\
\hline
\end{tabular}

\subsection{3. Điều kiện ẩm đối với SXNN}

\section{a) Mura}

Mưa là nguồn nước đến quan trọng cho cây trồng nói riêng và sự sống nói chung, là thành phần chủ yếu trong cán cân nước trên bề mặt và trạng thái ẩm trên đồng ruộng. Trong báo cáo này điều kiện nước đối với cây trồng được đánh giá theo một số đặc trưng về mưa (nguồn nước đến). Từ Bảng 8 nhận thấy tổng lượng mưa trung bình nhiều năm ở Kỳ Anh khoảng $2800 \mathrm{~mm}$, đây là nơi có lượng mưa lớn nhất trong tỉnh Hà Tĩnh. Theo tiêu chí về mùa mưa được sử dụng rộng rãi hiện nay ở nước ta: mùa mưa bao gồm những tháng có lượng mưa từ $100 \mathrm{~mm}$ trở lên, thì ở Kỳ Anh mùa mưa chính từ tháng VIII đến hết tháng XII, chưa kể một mùa mưa phụ vào tiết Tiểu Mãn khoảng tháng $\mathrm{V}$, tháng VI. Mưa nhiều nhất vào 3 tháng: VIII, IX, X. Vào tháng VII do ảnh hưởng của gió tây khô nóng nên lượng mưa giảm dưới 100mm (tháng VII: $97.8 \mathrm{~mm}$ ) mùa mưa bị gián đoạn tạm thời.

Bảng 8. Lượng mưa trung bình tháng, năm ở huyện Kỳ Anh và các vùng lân cận (mm).

\begin{tabular}{|c|c|c|c|c|c|c|c|c|c|c|c|c|c|}
\hline Trạm & I & II & III & IV & $\mathbf{V}$ & VI & VII & VIII & IX & $\mathbf{X}$ & XI & XII & Năm \\
\hline Hà Tĩnh & 99,9 & 67,4 & 56,2 & 71,6 & 138,6 & 135,3 & 130,3 & 218,9 & 502,1 & 716,2 & 344,1 & 163,3 & 2653,3 \\
\hline $\begin{array}{l}\text { Hương } \\
\text { Khê }\end{array}$ & 44,7 & 45,1 & 63,0 & 97,7 & 209,2 & 170,8 & 147,5 & 262,9 & 503,2 & 562,9 & 202,9 & 71,4 & 2379,7 \\
\hline Kỳ Anh & 107,1 & 70,8 & 61,2 & 62,5 & 152,9 & 121,6 & 97,8 & 246,5 & 555,1 & 763,0 & 399,1 & 199,5 & 2837,1 \\
\hline $\begin{array}{l}\text { Tuyên } \\
\text { Hoá }\end{array}$ & 52,5 & 41,7 & 48,8 & 70,6 & 151,8 & 146,3 & 135,7 & 221,6 & 493,3 & 666,6 & 215,2 & 83,4 & 2332,2 \\
\hline Ba Đồn & 50,2 & 51,0 & 43,4 & 55,8 & 103,3 & 98,2 & 74,7 & 159,2 & 428,4 & 621,8 & 271,0 & 100,5 & 2001,4 \\
\hline
\end{tabular}

Như vậy, ở huyện Kỳ Anh lượng mưa phân bố không đều. Trong suốt thời gian từ tháng II đến tháng IV (3 tháng) lượng mưa rất nhỏ chỉ chiếm khoảng 16-20\% tổng lượng mưa năm. Đặc điểm này gây những khó khăn cho sản xuất nếu không có các công trình thuỷ lợi.

\section{b) Khả năng đảm bảo nước cho $S X N N$}

Tổng lượng mưa trung bình nhiều năm ở Kỳ Anh và các huyện lân cận phổ biến từ 2000$2900 \mathrm{~mm}$. Trong đó vụ hè thu (từ tháng $\mathrm{V}$ đến tháng $\mathrm{X}$ ) phổ biến 1382-1829 mm, chiếm 63$71 \%$ so với tổng lượng mưa năm. Vụ Đông xuân từ tháng I đến tháng $\mathrm{V}$, lượng mưa phổ biến từ 304-460 mm, chiếm tỷ lệ từ 19-22\% so với tổng lượng mưa năm (Bảng 9). 
Bảng 9. Phân bố lượng mưa trung bình năm, mùa vụ (mm).

\begin{tabular}{cccccc}
\hline \multirow{2}{*}{ Địa điểm } & \multicolumn{2}{c}{ Từ tháng VI-X (vụ Hè Thu) } & \multicolumn{2}{c}{ Từ tháng I-V (vụ Đông Xuân) } \\
\cline { 2 - 6 } & $\begin{array}{c}\text { Tổng lượng } \\
\text { mưa năm }\end{array}$ & $\begin{array}{c}\text { Tổng lượng mưa } \\
\text { vụ Hè Thu }\end{array}$ & $\begin{array}{c}\text { So với lượng } \\
\text { mưa năm (\%) }\end{array}$ & $\begin{array}{c}\text { Tổng lượng mưa } \\
\text { vụ Đông Xuân }\end{array}$ & $\begin{array}{c}\text { So với lượng } \\
\text { mưa năm (\%) }\end{array}$ \\
\hline Hà Tĩnh & 2653,3 & 1702,8 & 23 & 433,7 & 64 \\
Hương Khê & 2379,7 & 1647,3 & 22 & 459,7 & 69 \\
Kỳ Anh & 2887,6 & 1829,7 & 22 & 442,2 & 63 \\
Tuyên Hóa & 2332,2 & 1663,5 & 19 & 365,4 & 71 \\
Ba Đồn & 2001,4 & 1382,3 & 20 & 303,7 & 69 \\
\hline
\end{tabular}

Tuy có lượng mưa dồi dào như vậy, nhưng trên thực tế SXNN hàng năm vẫn bị thiếu nước, có năm tình hình thiếu nước trở nên nghiêm trọng, vì lượng mưa phân bố không đều, lượng trữ nước không bảo đảm, quản lý, điều tiết và sử dụng nước có lúc chưa hợp lý. Những tháng mưa ít như tháng II, III, IV và các tháng vào giữa mùa hè do thời tiết gió Tây khô nóng kéo dài thường gặp hạn thiếu nước cho tưới tiêu, có năm xảy ra hạn, thậm chí hạn nghiêm trọng cây trồng bị thiếu ẩm nhất là cây trồng cạn.

c) Đánh giá lương mura tích luỹ đầu mùa và cuối mùa

Để xác định cơ cẩu thời vụ cho các cây trồng cạn trông chờ vào nước mưa ngoài yếu tố nhiệt độ còn phải xác định tổng lượng mưa tích luỹ đầu mùa và cuối mùa $[1,3,14]$.

Bảng 10. Suất bảo đảm (P\%) lượng mưa tích luỹ trước và sau các ngưỡng ở Kỳ Anh.

\begin{tabular}{cccccc}
\hline $\mathbf{P ( \% )}$ & $\begin{array}{c}\text { Tích luỹ trước } \\
\mathbf{7 5} \mathbf{~ m m}\end{array}$ & $\begin{array}{c}\text { Tích luỹ trước } \\
\mathbf{2 0 0 \mathbf { m m }}\end{array}$ & $\begin{array}{c}\text { Tích lũy sau } \\
\mathbf{5 0 0} \mathbf{~ m m}\end{array}$ & $\begin{array}{c}\text { Tích lũy sau } \\
\mathbf{3 0 0} \mathbf{~ m m}\end{array}$ & $\begin{array}{c}\text { Tích lũy sau } \\
\mathbf{1 0 0} \mathbf{~ m m}\end{array}$ \\
\hline 20 & $09 / \mathrm{I}$ & $01 / \mathrm{III}$ & $17 / \mathrm{XI}$ & $02 / \mathrm{XII}$ & $16 / \mathrm{XII}$ \\
40 & $16 / \mathrm{I}$ & $08 / \mathrm{III}$ & $12 / \mathrm{XI}$ & $24 / \mathrm{XI}$ & $09 / \mathrm{XII}$ \\
60 & $23 / \mathrm{I}$ & $17 / \mathrm{III}$ & $04 / \mathrm{XI}$ & $27 / \mathrm{X}$ & $03 / \mathrm{XII}$ \\
80 & $30 / \mathrm{I}$ & $30 / \mathrm{III}$ & $22 / \mathrm{X}$ & $05 / \mathrm{XI}$ & $24 / \mathrm{XI}$ \\
95 & $09 / \mathrm{II}$ & $28 / \mathrm{IV}$ & $29 / \mathrm{IX}$ & $25 / \mathrm{X}$ & $14 / \mathrm{XI}$ \\
\hline
\end{tabular}

Thời điểm tích luỹ được lượng mưa $75 \mathrm{~mm}$ kể từ $1 / \mathrm{I}$ là thời điểm bắt đầu gieo trồng cây màu vụ đông xuân và $200 \mathrm{~mm}$ là thời điểm đủ nước để gieo trồng lúa đông xuân. Biết thời điểm lượng mưa tích luỹ sau mốc (thời điểm còn tiếp tục mưa) $500 \mathrm{~mm}, 300 \mathrm{~mm}, 100 \mathrm{~mm}$ đến thời điểm ngày $31 /$ XII để biết được khả năng gieo cấy vụ lúa nước thứ hai hoặc một vụ màu ngắn ngày $[12,14]$.

Từ phân tích trên ta có thể biết được thời điểm bắt đầu và kết thúc mùa mưa và biết được đến thời điểm nào trong năm còn mưa bao nhiêu nữa để có thể sắp xếp được mùa vụ phù hợp cho từng loại cây trồng. Qua kết quả tính lượng mưa luỹ tích trước và sau các ngưỡng ta thấy cứ 5 năm thì có 4 năm (suất bảo đảm $80 \%$ ) từ cuối tháng $\mathrm{I}$ hoặc đầu tháng II và đầu tháng III, ở hầu hết các nơi ở Kỳ Anh đã lũy tích được $75 \mathrm{~mm}$ mưa và từ cuối tháng III đến cuối tháng $\mathrm{V}$ đã lũy tích được $200 \mathrm{~mm}$ mưa. Tương tự ta thấy cứ 10 năm có 8 năm từ đầu tháng $X$ đến cuối tháng $X$ còn mưa ít nhất là $500 \mathrm{~mm}$ và từ giữa tháng $X$, đầu tháng $X I$ còn mưa ít nhất là $300 \mathrm{~mm}$ và từ đầu tháng XI đến cuối tháng XI tháng còn mưa ít nhất $100 \mathrm{~mm}(\mathrm{Bảng}$ $10)$.

d) Xác suất tuần khô, tuần ướt

Trong vùng khí hậu nhiệt đới gió mùa ngay trong những tháng mùa mưa cũng thường xuất hiện các đợt khô hạn, gây cản trở cho $\mathrm{SXNN}$, vì vậy một đặc trưng cần được quan tâm là xác suất 2 và 3 tuần khô (tuần khô là tuần có lượng mưa $<30 \mathrm{~mm}$ ) liên tục để có biện pháp tưới tiêu hoặc bố trí mùa vụ nhằm tận dụng, hoặc né tránh được các tuần khô $[5,14]$. Ở Kỳ 
Anh xác suất xuất hiện 2,3 tuần khô liên tục chủ yếu xuất hiện trong mùa ít mưa từ tháng I năm trước đến tháng IV năm sau. Tương tự như vậy tuần ướt là tuần có lượng mưa $\geq 30 \mathrm{~mm}$, tuần ướt liên tục tùy từng nơi mà có thể xảy ra sớm hay muộn. Đây chính là tính chất riêng biệt về diễn biến của mưa ở Kỳ Anh, cần phải được đặc biệt lưu ý trong sản xuất vụ hè thu và vụ mùa. Vào mùa mưa: các tháng đầu mùa mưa $(\mathrm{V}, \mathrm{VI}, \mathrm{VII})$ do hoạt động của gió tây khô nóng nên xác suất 3 tuần ướt liên tục thấp, nhưng vào tháng cuối mùa mưa (IX, $\mathrm{X}, \mathrm{XI})$ xác suất 3 tuần ướt liên tục luôn cao do hoạt động mạnh của các hệ thống gây mưa lớn kéo dài như bão, ATNĐ, dải hội tụ nhiệt đới,... (Bảng 11).

Bảng 11. Tần suất tuần khô, tuần ướt tại Kỳ Anh và khu vực lân cận (\%).

\begin{tabular}{|c|c|c|c|c|c|c|c|c|c|c|c|c|}
\hline \multirow{2}{*}{$\begin{array}{c}\text { Tháng } \\
\text { Tuần }\end{array}$} & \multicolumn{3}{|c|}{ I } & \multicolumn{3}{|c|}{ II } & \multicolumn{3}{|c|}{ III } & \multicolumn{3}{|c|}{ IV } \\
\hline & 1 & 2 & 3 & 1 & 2 & 3 & 1 & 2 & 3 & 1 & 2 & 3 \\
\hline $2 \mathrm{Tk}$ & 24,4 & 25,6 & 34,9 & 31,4 & 57,9 & 71,8 & 71,0 & 82,2 & 54,8 & 78,6 & 73,9 & 62,1 \\
\hline $3 \mathrm{Tk}$ & 11,2 & 16,0 & 19,6 & 24,4 & 49,6 & 62,6 & 64,3 & 60,6 & 48,7 & 69,3 & 58,0 & 49,7 \\
\hline $2 \mathrm{Pu}$ & 45,9 & 14,0 & 23,3 & 20,1 & 11,0 & 4,1 & 14,0 & 0,8 & 5,1 & 1,7 & 5,4 & 4,2 \\
\hline $3 \mathrm{Pu}$ & 14,5 & 7,3 & 10,6 & 8,6 & 2,7 & 3,1 & 1,3 & 0,2 & 0,7 & 0,6 & 1,1 & 2,3 \\
\hline Tháng & \multicolumn{3}{|c|}{$\mathbf{V}$} & \multicolumn{3}{|c|}{ VI } & \multicolumn{3}{|c|}{ VII } & \multicolumn{3}{|c|}{ VIII } \\
\hline Tuần & 1 & 2 & 3 & 1 & 2 & 3 & 1 & 2 & 3 & 1 & 2 & 3 \\
\hline $2 \mathrm{Tk}$ & 52,1 & 29,1 & 30,3 & 30,6 & 42,7 & 48,2 & 67,4 & 66,6 & 62,0 & 42,5 & 47,1 & 22,3 \\
\hline $3 \mathrm{Tk}$ & 26,0 & 19,0 & 17,3 & 20,0 & 30,5 & 39,9 & 55,2 & 53,8 & 43,6 & 31,9 & 28,3 & 12,2 \\
\hline $2 \mathrm{Pu}$ & 19,4 & 14,6 & 40,1 & 24,8 & 12,5 & 16,3 & 4,7 & 3,7 & 6,8 & 22,2 & 16,5 & 47,1 \\
\hline $3 \mathrm{Pu}$ & 6,7 & 10,9 & 21,4 & 8,9 & 6,2 & 4,1 & 0,9 & 1,1 & 3,8 & 9,9 & 12,4 & 33,8 \\
\hline Tháng & \multicolumn{3}{|c|}{ IX } & \multicolumn{3}{|c|}{$\mathbf{X}$} & \multicolumn{3}{|c|}{ XI } & \multicolumn{3}{|c|}{ XII } \\
\hline Tuần & 1 & 2 & 3 & 1 & 2 & 3 & 1 & 2 & 3 & 1 & 2 & 3 \\
\hline $2 \mathrm{Tk}$ & 19,0 & 25,6 & 8,1 & 16,3 & 12,7 & 12,8 & 25,3 & 7,8 & 22,7 & 25,9 & 20,9 & 29,8 \\
\hline $3 \mathrm{Tk}$ & 19,0 & 12,8 & 5,7 & 8,9 & 6,3 & 9,9 & 9,5 & 4,8 & 14,1 & 11,1 & 12,8 & 17,4 \\
\hline $2 \mathrm{Pu}$ & 46,8 & 66,1 & 78,6 & 69,8 & 67,2 & 64,2 & 53,6 & 70,3 & 50,2 & 44,9 & 23,3 & 30,7 \\
\hline $3 \mathrm{Pu}$ & 41,6 & 62,1 & 71,5 & 61,0 & 57,9 & 50,9 & 47,6 & 56,2 & 38,8 & 20,4 & 14,0 & 24,2 \\
\hline
\end{tabular}

Ghi chú: 2Tk: hai tuần khô, 3Tk: ba tuần khô; 2Pu: hai tuần uớt, 3Pu: ba tuần uoót.

e) Độ ẩm tương đối

Hàng năm ở Kỳ Anh có độ ẩm không khí khá cao, ngay trong những tháng khô hạn nhất của mùa hè, độ ẩm trung bình tháng vẫn thường trên $70 \%$.

Thời kỳ có độ ẩm cao nhất ở Kỳ Anh thường xảy ra vào những tháng cuối mùa

đông khi khối không khí cực đới lục địa tràn về qua đường biển và khối không khí nhiệt đới biển Đông luân phiên hoạt động gây ra mưa phùn, độ ẩm không khí rất lớn đó là thời kỳ nhiều mưa phùn gió bấc vào tháng 2 , tháng 3 . Thời kỳ có độ ẩm không khí thấp nhất là tháng 6, 7 ứng với thời kỳ gió Tây khô nóng hoạt động mạnh mẽ nhất.

Kết quả tính toán ở bảng 12 cho thấy: Độ ẩm không khí trung bình năm tính chung cho cả huyện Kỳ Anh khoảng $84 \%$, phân bố tương đối đồng đều ở các vùng và có sự biến động lớn giữa các tháng mùa cuối mùa đông vàđầu mùa hè, tháng có độ ẩm thấp nhất là tháng VI và VII (71-73\%), độ ẩm cao nhất là tháng I, II từ 90-92\%.

Bảng 12. Độ ẩm không khí trung bình tháng, năm ở Kỳ Anh và các vùng lân cận.

\begin{tabular}{|c|c|c|c|c|c|c|c|c|c|c|c|c|c|}
\hline \multirow{2}{*}{ Trạm } & \multicolumn{12}{|c|}{ Tháng } & \multirow{2}{*}{ Năm } \\
\hline & I & II & III & IV & $\mathbf{V}$ & VI & VII & VIII & IX & $\mathbf{X}$ & XI & XII & \\
\hline Vinh & 89,1 & 90,8 & 90,3 & 88,1 & 81,3 & 75,0 & 73,6 & 80,0 & 85,4 & 86,9 & 85,8 & 86,0 & 84,4 \\
\hline
\end{tabular}




\begin{tabular}{|c|c|c|c|c|c|c|c|c|c|c|c|c|c|}
\hline \multirow{2}{*}{ Trạm } & \multicolumn{12}{|c|}{ Tháng } & \multirow{2}{*}{ Năm } \\
\hline & I & II & III & IV & $\mathbf{V}$ & VI & VII & VIII & IX & $\mathbf{X}$ & XI & XII & \\
\hline Hương Khê & 89,4 & 90,3 & 89,0 & 85,8 & 80,8 & 77,1 & 74,8 & 81,4 & 85,9 & 88,4 & 88,0 & 88,0 & 84,9 \\
\hline Kỳ Anh & 90,4 & 91,8 & 90,3 & 87,5 & 80,3 & 73,4 & 71,3 & 77,3 & 85,3 & 87,6 & 87,1 & 88,0 & 84,3 \\
\hline Hà Tĩnh & 90,0 & 91,8 & 90,7 & 87,4 & 81,0 & 75,7 & 73,6 & 79,4 & 85,5 & 87,6 & 87,4 & 87,5 & 84,8 \\
\hline Tuyên Hoá & 90,1 & 90,1 & 88,2 & 84,8 & 80,3 & 75,1 & 73,4 & 79,8 & 87,1 & 89,8 & 89,4 & 89,4 & 85,0 \\
\hline Ba Đồn & 88,2 & 89,6 & 88,9 & 87,1 & 81,6 & 75,0 & 73,0 & 77,8 & 85,0 & 87,1 & 86,6 & 86,9 & 84,0 \\
\hline
\end{tabular}

\subsection{Thiên tai và các hiện tương thời tiết cục đoan đối với $S X N N$}

\subsubsection{Bão và áp thấp nhiệt đới}

Theo số liệu quan trắc, thông thường mùa mưa bão ở Kỳ Anh từ tháng 9 đến tháng 11. Tuy nhiên trong những năm gần đây, xu hướng bão có sự thay đổi. Cụ thể, khoảng thời gian có khả năng xảy ra bão trong năm được mở rộng hơn, có thể từ tháng 8 đến tháng 12 . Số cơn bão đổ bộ vào Kỳ Anh thường ít hơn, nhưng sức tàn phá của nó thường khá mạnh.

Ở Kỳ Anh bình quân mỗi năm từ 1 dến 1,6 cơn. Bão ở đây thường xuất hiện từ tháng IX đến tháng XI, gây nhiều hậu quả xấu đến sản xuất và đời sống của nhân dân trong vùng. Do ảnh hưởng của bão thường gây ra mưa lớn, ở Kỳ Anh bình quân 1 cơn bão hoặc áp thấp nhiệt đới có thể mưa từ 100-200 mm, có nơi 400-500 mm vì vậy dễ gây lũ lụt lớn. Một số năm gần đây, Kỳ Anh nằm trong vùng tâm một số cơn bão. Tốc độ gió đạt tới trên cấp 12 (trên $32,7 \mathrm{~m} / \mathrm{s}$ ). Hầu hết các cơn bão đổ bộ vào đều có lượng mưa lớn từ 200-500 mm trên diện rộng, gây thiệt hại lớn cho $\mathrm{SXNN}$ và thủy sản.

\subsubsection{Gió Tây khô nóng (GTKN)}

Gió Tây khô nóng: Là một loại hình đặc biệt ở Kỳ Anh nói riêng và khu IV nói chung. GTKN xuất phát từ áp thấp khô nóng Ân-Miến hoặc từ vịnh Ben-gan qua dải Trường Sơn trước khi đi vào Kỳ Anh. Tại đây xảy ra hiện tượng "phơn” nghĩa là hơi nước được giữ lại ở phía tây Trường Sơn, khi xuống đông Trường Sơn thì trở nên khô và nóng, nhưng thường chỉ xuất hiện từng đợt, nhiệt độ cao nhất lớn hơn $35^{\circ} \mathrm{C}$, độ ẩm thấp nhất dưới $55 \%$. Bình quân số ngày gió Tây khô nóng ở huyện Kỳ Anh là 30-50 ngày/năm, thường bắt đầu từ tháng III, kết thúc tháng IX cao điểm là tháng VII (Bảng 13). Các đợt GTKN thường được kết thúc bằng những đợt mưa, dông, mưa rào mạnh do tăng áp, ảnh hưởng bão, áp thấp nhiệt đới hoặc dải hội tụ nhiệt đới.

Gió tây khô nóng gây rất nhiều tác hại cho SXNN. Vào tháng III, tháng IV lúa đang làm đòng, trỗ bông mà gặp GTKN năng suất bị giảm sút nghiêm trọng, có khi bị mất trắng. GTKN làm tăng lượng bốc hơi nước trong không khí, cây cối bị mất nước, dễ bị chết, rất nguy hại cho mùa màng.

Để hạn chế tác hại của GTKN phải đảm bảo đủ nước tưới trong những ngày nắng nóng, gieo trồng đúng thời vụ, trồng cây gây rừng chắn gió, các kho tàng chuồng trại phải đúng quy cách, thoáng mát, hạn chế ảnh hưởng của GTKN.

Bảng 13. Số ngày gió tây khô nóng ở Kỳ Anh và một số khu vực lân cận.

\begin{tabular}{|c|c|c|c|c|c|c|c|c|c|}
\hline \multirow{2}{*}{ Trạm } & \multicolumn{8}{|c|}{ Tháng } & \multirow[b]{2}{*}{ Năm } \\
\hline & II & III & IV & $\mathbf{V}$ & VI & VII & VIII & IX & \\
\hline Vinh & 0,3 & 1,2 & 7,3 & 9,9 & 13,4 & 6,4 & 0,7 & 0,0 & 39,2 \\
\hline Hà Tĩnh & 0,2 & 0,7 & 1,5 & 7,2 & 9,4 & 13,8 & 6,5 & 0,0 & 39,3 \\
\hline Kỳ Anh & 0,0 & 0,7 & 2,4 & 8,4 & 8,9 & 12,5 & 5,9 & 0,7 & 39,5 \\
\hline Tuyên Hoá & 0,5 & 2,3 & 5,8 & 11,2 & 8,4 & 11,6 & 6,0 & 1,6 & 47,4 \\
\hline
\end{tabular}




\begin{tabular}{cccccccccc}
\hline \multirow{2}{*}{ Trạm } & \multicolumn{10}{c}{ Tháng } & \\
\cline { 2 - 8 } & II & III & IV & V & VI & VII & VIII & IX & Năm \\
\hline Đồng Hới & 0,0 & 0,3 & 1,2 & 7,3 & 9,9 & 13,4 & 6,4 & 0,7 & 39,2 \\
\hline
\end{tabular}

\subsubsection{Về hạn hán và xâm nhập mặn}

Ở bên sườn khuất gió, hiệu ứng phơn, do gió tây-nam vượt qua dãy Trường Sơn, đã gây ra những đợt gió tây khô nóng kéo dài với nhiệt độ cao, độ ẩm thấp, làm gia tăng tính khắc nghiệt của hạn hán vốn có tốc độ diễn biến nhanh tại xã Kỳ Nam, tác động mạnh đến môi trường sinh thái trong vùng, trong đó đáng chú ý là tình trạng cạn kiệt nhanh nguồn nước dân sinh của vùng cao gần núi và thiếu nước dân sinh của vùng thấp ven biển, vì nước mặn xâm nhập sâu vào nội đồng và vùng dân cư. Nước biển đã tiển sát vào hàng phi lao trước đây trồng cách mép biển $20-30 \mathrm{~m}$, mặn lấn sâu vào nội đồng và khu dân cư. Khô hạn trước đây chỉ kéo dài 2-3 tháng, nay tới 4-5 tháng, thậm chí từ năm 2004 đến nay, hạn hán trên đất Kỳ Nam diễn ra 6 tháng (từ tháng 3-8). Những cánh đồng trồng được 2 vụ lúa trước kia, nay chỉ cấy được một vụ với năng suất thấp hoặc không trỗ đòng. Hạn hán kéo dài cũng gây hậu quả nghiêm trọng đối với kinh tế vườn: Năng suất các loại cây rau màu giảm 20-30\%; Cây ăn quả bị chết, rụng quả, năng suất giảm $50 \%$, chất lượng kém; Đồng cỏ bị khô táp, đàn gia súc giảm 1/3 tổng đàn; Một số giống cây trồng bị thoái hoá, như na, khoai môn [11].

\subsubsection{Mưa lớn, xói mòn, thoái hóa đất}

Do Kỳ Anh nằm ở bên sườn đón gió đông-nam từ biển thổi vào, nên trong thời kỳ mùa mưa, nhất là ba tháng 9-11, Kỳ Anh phải hứng chịu nhiều trận mưa với cường độ lớn, tới trên $500 \mathrm{~mm} / \mathrm{ngày}$. Lượng mưa lớn, tập trung, trong khi địa hình lại có độ dốc cao, đã dẫn đến hiện tượng xói mòn, rửa trôi mạnh. Đất vốn đã bạc màu do khô hạn, lại bị rửa trôi do mưa lũ lớn, nên suy thoái nghiêm trọng. Các loại cây trồng trong vườn gia đình có biểu hiện không cho thu hoạch, như cây na, trước kia vùng này trồng rất phù hợp cho quả khá, nhưng vài năm trở lại đây, cây na chỉ có hoa mà không kết trái, hoặc có quả nhưng lại bị khô quắt do đất bạc màu, thiếu dinh dưỡng, do khô hạn. Khoai lang bị hà nhiều hoặc không có củ, chuối đang xanh tốt đến mùa khô, nóng bị lụi đần từ ngọn xuống [11]. Bão, lũ, mưa lớn gây thiệt hại khá nặng nề cho SXNN và thủy sản, làm sụt giảm chất lượng tuyến đê ngăn mặn. Số diện tích bị nhiễm mặn tăng dần theo từng năm, đến nay ở xã Kỳ Nam huyện Kỳ Anh có tới gần 10 ha diện tích đất đã bị nhiễm mặn, thành hoang hóa. Giếng nước sinh hoạt ở vùng thấp đã bị nhiễm mặn thành nước lợ [11].

\section{Kết luận}

Do địa hình Kỳ Anh nằm trên dải đất hẹp ven biển có độ dốc lớn, Kỳ Anh chịu tác động của nhiều loại thiên tai đan xen lẫn nhau, điển hình là hạn hán, xâm nhập mặn, mưa lớn, bão lũ gây tác hại kép đối với kinh tế, xã hội và dân sinh trong vùng. Phần lớn lãnh thổ huyện Kỳ Anh có nhiệt độ trung bình năm từ $24-25^{\circ} \mathrm{C}$. Mùa nóng là thời kỳ có nhiệt độ từ $24-29^{\circ} \mathrm{C}$ và mùa lạnh là thời kỳ có nhiệt độ nhỏ hơn $18-21^{\circ} \mathrm{C}$. Mùa lạnh ở đây không quá khắc nghiệt, tuy nhiên cũng có thời kỳ xảy ra các đợt rét hại ảnh hưởng đến $\mathrm{SXNN}$.

Biên độ nhiệt độ các tháng đạt $4,4-7,1^{\circ} \mathrm{C}$. Biên độ nhiệt độ năm khoảng $5.0-6.0^{\circ} \mathrm{C}$ như vậy ở Kỳ Anh có khả năng trồng cây công nghiệp và cây ăn quả lâu năm có biên độ sinh thái rộng. Tổng nhiệt năm dao động từ $8.000-8.500^{\circ} \mathrm{C}$. Với nguồn nhiệt này phần lớn diện tích vùng thung lũng bằng phẳng trồng được 2 vụ lúa, ở vùng núi cao chỉ trồng được 1 vụ lúa và 1 vụ màu.

Nhờ Đèo Ngang đón gió đông bắc vào cuối mùa hè đầu mùa đông, Kỳ Anh trở thành trung tâm mưa lớn của Hà Tĩnh. Ở Kỳ Anh lượng mưa phổ biến là 2600-3000 mm đủ đáp ứng cho nhu cầu $\mathrm{SXNN}$ cả năm nói chung. Tuy nhiên lượng mưa phân bố không đều trong năm. Lượng mưa tích lũy đầu mùa cuối mùa, xác suất $2-3$ tuần khô ướt đã thể hiện quy luật 
khá rõ ràng về sự phân bố mưa trong năm ở Kỳ Anh, vì vậy khi gieo trồng cần lưu ý thừa nước trong mùa mưa nhưng lại thiếu nước trong mùa khô, thậm chí xuất hiện lũ lụt, hạn hán gay gắt.

Đóng góp của tác giả: Xây dựng ý tưởng nghiên cứu: D.V.K.; Lựa chọn phương pháp nghiên cứu: D.V.K., Đ.Q.K.; Viết bản thảo bài báo: D.V.K., Đ.Q.K.; Chỉnh sửa bài báo: D.V.K., Đ.Q.K.

Lời cảm ơn: Nghiên cứu này được thực hiện dưới sự hợp tác và tài trợ của tổ chức $\mathrm{CARE}$ Việt Nam và ICRAF Tổ chức Nông Lâm Thế giới. Bên cạnh đó, tập thể tác giả trân trọng cảm ơn sự giúp đỡ của, Đài Khí tượng Thủy văn tỉnh Hà Tĩnh, Hội nông dân, Hội phụ nữ huyện Kỳ Anh tỉnh Hà Tĩnh trong quá trình khảo sát và thực hiện nghiên cứu này.

Lời cam đoan: Tập thể tác giả cam đoan bài báo này là công trình nghiên cứu của tập thể tác giả, chưa được công bố ở đâu, không được sao chép từ những nghiên cứu trước đây; không có sự tranh chấp lợi ích trong nhóm tác giả.

\section{Tài liệu tham khảo}

1. Viết, N.V. Khai thác tài nguyên khí hậu nông nghiệp Việt Nam, NXB Tài nguyên, Môi trường và Bản đồ Việt Nam, 2012.

2. WMO. Guide to Agricultural Meteorological Practices, No. 134, 2010, 50-120.

3. Tài nguyên khí hậu nông nghiệp lãnh thổ các nước XHCN châu Âu. Viện Hàn lâm Khoa học Bulgaria, 1971, 210-252.

4. Konstantinov, A.R. Bốc hơi từ đồng ruộng. Len. 1968, 3-15.

5. Dmitrienko, V.P. Những giá trị tối ưu và quy luật ảnh hưởng của lượng mưa và nhiệt độ đến năng suất cây trồng. Ucraina 1969, 84, 252-273.

6. Khảm, D.V.; Ly, X.G. Ảnh hưởng của biến đổi khí hậu đến nắng suất lúa ở miền Bắc Việt Nam. Tạp chi Khí tương Nam Kinh (Trung Quốc) 2004, 55-64.

7. Chen, C.; Mcnairn, H. A neural network integrated approach for rice crop monitoring. Int. J. Remote Sens. 2006, 27, 1367-1393.

8. Kotera, A.; Toshihiro, S.; Masayuki, Y. Determining the Spatial Pattern of Rice Cropping Schedules using Time-Series Satellite Imagery of the Red River Delta, Vietnam. Int. J. Geoinformatics 2007, 3(4), 366-374.

9. Ngũ̃, N.Đ.; Hiệu, N.T. Khí hậu và tài nguyên khí hậu Việt Nam. NXB Nông nghiệp, 2004.

10. Thứ, L.Đ. Tăng cường năng lực công tác thu thập số liệu KTNN phục vụ phát triển nông nghiệp bền vững và an ninh lương thực cho thế kỷ 21. Tạp chi Khi tượng Thưy văn 2001, 10, 27-29.

11. Cục thống kê Hà Tĩnh, Niên giám thống kê Hà Tĩnh 2019.

12. Đáp, B.H. Cở sở khoa học của vụ đông, NXB Nông nghiệp, 1978.

13. Khảm, D.V; Ly, X.G. Nghiên cứu biến đổi khí hậu và biến đổi năng suất tiềm năng khí hậu ở miền Bắc Việt Nam. Tạp chi Khi tượng Nam Kinh (Trung Quốc) 2002, 30 34.

14. Oldeman, L.R.; Frer, M. Nghiên cứu khí hậu nông nghiệp nhiệt đới ẩm Đông Nam Á. Bản dịch NXB Nông nghiệp, 1988.

15. Korova, L.A.; Burukun, B.M. Những phương pháp toán học trong đánh giá tài nguyên khí hậu nông nghiệp. Len. 1999, 41-45.

16. Kadbhane, S.J; Manekar, V.L. Development of agro-climatic grape yield model with future prospective. Ital. J. Agrometeorol. 2021, 89-103.

17. Thắng, N.V.; Khiêm, M.V.; Mậu, N.Đ.; Trí, T.Đ. Nghiên cứu xác định chỉ tiêu hạn hán cho vùng Nam trung bộ. Tạp chí Khí tượng Thủy văn 2014, 3, 49-55. 
18. Sơn, N.H.; Dương, T.H. Nghiên cứu, lựa chọn chỉ tiêu đánh giá và phân vùng khí hậu nông nghiệp khu vực Bắc Trung Bộ và Duyên hải Miền Trung. Tạp chí Khí tương Thủy văn 2015, 655, 37-42.

19. Vinh, P.T.; Bình, N.T.; Hương, B.T.T. Đánh giá ảnh hưởng của điều kiện khí hậu nông nghiệp đến cây trồng ngăn ngày ở khu vực Ninh Thuận và Bình Thuận. Tạp chí Khoa hoc về trái đất 2013, 364-373.

20. Khảm, D.V.; Thái, T.H. Nghiên cứu đặc điểm diễn biến của hiện tượng rét hại khu, vực Tây Bắc và khả năng dự báo. Tạp chí Khí twợng Thủy văn 2011, 604, 43-48.

21. Anh, N.N.; Quyen, N.H; Tam, T.T.; Yen. D.H.; Kham, D.V. Zoning agro-climatic factors and evaluating adaptation ability of arabica coffee in Muong Ang district, Dien Bien province. Tạp chí Khoa học Biến đổi khí hậu 2019, 99-112.

22. Tuấn, Đ.T. Cơ sở khoa học của thời vụ gieo trồng. NXB Nông nghiệp, 1979.

23. Kham, D.V; Quyen, N.H. Assessing the impact of minimum temperature on crop over Winter season in northwest mountain areas of Vietnam. J. Sci. 2012, 92-99.

24. Sơn, N.V.; Khảm, D.V.; Tâm, T.T.; Hoa, N.H. Một số đánh giá tác động của thiên tai đến sản xuất nông nghiệp đề xuất một số biện pháp phòng tránh tỉnh Lào Cai. Tạp chi Khoa học Biến đổi khi hậu 2020, 63-66.

25. Huỳnh, L.Q.; Viết, N.V; Cường, N.M. Cơ sở khí hậu nông nghiệp của thời vụ lúa mùa ở miền Bắc Việt Nam. Tạp chi Khí tượng Thủy văn 1979, 8, 15-20.

\title{
Evaluation of climate characteristics and agro-climatic conditions Ky Anh district, Ha Tinh province
}

\author{
Duong Van Kham ${ }^{1 *}$, Dang Quoc Khanh ${ }^{2}$ \\ ${ }^{1}$ Vietnam Institute of Meteorology, Hydrology and Climate Change; \\ dvkham.kttv@gmail.com \\ ${ }^{2}$ Vietnam Meteorological and Hydrological Administration; khanhdangkhtc@gmail.com
}

\begin{abstract}
Ky Anh is a district with complicated meteorological conditions, always facing a harsh climate, floods in the rainy season, prolonged droughts in the dry season, and fierce hot and dry southwest winds that greatly affect the country agricultural production. On the basis of meteorological data and agricultural production data in Ky Anh, applying statistical methods in climate, agro-climatology, the article has systematically assessed the climatic conditions climate, agricultural climate in Ky Anh. Includes: light conditions with a total of 1716 hours of sunshine per year. The average annual temperature is from $24-25^{\circ} \mathrm{C}$. The monthly temperature range reaches $4.4-7.1^{\circ} \mathrm{C}$, the annual temperature range is about 5.0 $6.0^{\circ} \mathrm{C}$. The total annual temperature ranges from 8,000 to $8,500^{\circ} \mathrm{C}$. The average rainfall in Ky Anh is $2600-3000 \mathrm{~mm}$, but the rainfall is unevenly distributed throughout the year. The cumulative rainfall at the beginning of the season, at the end of the season, the probability of 2-3 wet and dry weeks has shown quite clear rules about the distribution of rain in the year. These results are an important scientific basis for agricultural production planning, crop restructuring, and disaster mitigation in Ky Anh.
\end{abstract}

Keywords: Climate; Agro-climatology. 